\title{
Strategy of Developing : Five Competitive Force Model Case Study: SMEs Fajarwonk
}

\author{
Mimi Kurnia Nengsih ${ }^{1}$, Ida Ayu Made Er Meytha Gayatri ${ }^{2}$, Wagini ${ }^{3}$, \\ Karona Cahya Susena ${ }^{4}$, Nia Indriasari ${ }^{5}$ \\ Faculty of Economics - Dehasen University $1,2,3,4,5$ \\ \{mimikurnianengsih@gmail.com ${ }^{1}$, cinta.gayatri@yahoo.cm², wagini980@gmail.com³, \\ karona.cs@unived.ac.id ${ }^{4}$,indriasari_nia@yahoo.com $\left.{ }^{5}\right\}$
}

\begin{abstract}
Micro, Small and Medium Enterprises (SMEs) is one of the government's efforts to tackle the problem of poverty. Empowerment and development of SMEs in Indonesia has several challenges that must be faced, including financial and non-financial problems. The Covid-19 pandemic has an impact on MSMEs, a lockdown policy that limits economic activity has resulted in a decrease in the amount of demand and disrupts supply chains for business actors. The researchers aimed to analyze the strategies Fajarwonk currently use and alternative strategies that could be developed by Fajarwonk using the five competitive forces model by Michael E. Porter. The results showed that the level of competition in the handicraft business of hanging leather was quite high, however, the threat from newcomers was quite low, while the bargaining power of customers was high due to different levels of purchasing power and the target market share, namely the middle to upper class. The bargaining power of suppliers is considered quite high and affects the quality of the final product. The strategies that Fajarwonk can develop are based on the identification of the five force model, namely: Adding more innovative product differentiation while maintaining quality, opening special outlets that are easily accessible to consumers, maintaining product quality supported by technological developments, marketing products through affiliate marketing.
\end{abstract}

Keywords: Strategy of Developing; Five competitive force model; SMEs Fajarwonk

\section{Introduction}

Micro, Small and Medium Enterprises (MSMEs) is one of the government's efforts to tackle the problem of poverty. A strong commitment from the Government has encouraged the development of MSMEs from year to year [1]. Based on data from the Ministry of Cooperatives, Small and Medium Enterprises in 2018, the number of MSME players was 64.2 million from the number of business actors in Indonesia with a workforce absorption of $97 \%$ and a contribution to the economy of $61.1 \%$. Based on these data, it shows that MSMEs have a central role in providing jobs.

The importance of the role of MSMEs in the economy is also strengthened by a Government 
Regulation as stated in Law Number 20 of 2008 in which MSMEs is one of the economic sectors that must be empowered and developed [2].

Empowerment and development of MSMEs in Indonesia have several challenges that must be faced, including financial and non-financial problems. To overcome this problem, the Government has attempted to provide solutions both from the managerial aspect, the capital aspect and the development of partnership programs with large companies. With the existence of various policies issued by the Government to encourage the growth and development of MSMEs, it has had a positive impact, where each year there is an increase in the number of MSMEs accompanied by an increase in the allocation of credit / financing for MSMEs by banks. The development of MSMEs in Indonesia occurs in all regions, one of which is Bengkulu Province, the number of active MSMEs in 2019 reached 1,700 spread across 10 City Districts.

The Covid-19 pandemic has an impact on MSMEs, a lockdown policy that limits economic activity has resulted in a decrease in the amount of demand and disrupts supply chains for business actors. The impact of covid-19 is mostly felt by MSME players in the field of supply of daily necessities, namely food and beverages[3].

The impact of the pandemic on sectors other than daily needs is also very pronounced, but unlike in the food and beverage sector. In the service sector, the pandemic has an impact that encourages MSMEs to be more creative and innovative in providing better services with the use of technology, as well as for other types of MSMEs that are required to be able to develop more effective strategies and create innovative products. in order to maintain business continuity. Strategy is a means of achieving goals to be achieved in the long term, which includes expansion, diversification and product development. To achieve a sustainable competitive advantage, the company must be able to adapt both externally and internally, have effective planning, implementation and evaluation of each strategy used. [4].

Fajarwonk is one of the MSMEs that utilizes hanging leather raw materials into products that are worth selling such as bags and special regional souvenirs. During the dawn, Fajarwonk must be able to adapt by developing strategies and innovative products to adapt to any changes, especially in production and marketing activities. From this phenomenon, the researcher aims to analyze the current strategy Fajarwonk uses and alternative strategies that Fajarwonk can develop using the five competitive forces model by Michael E. Porter.

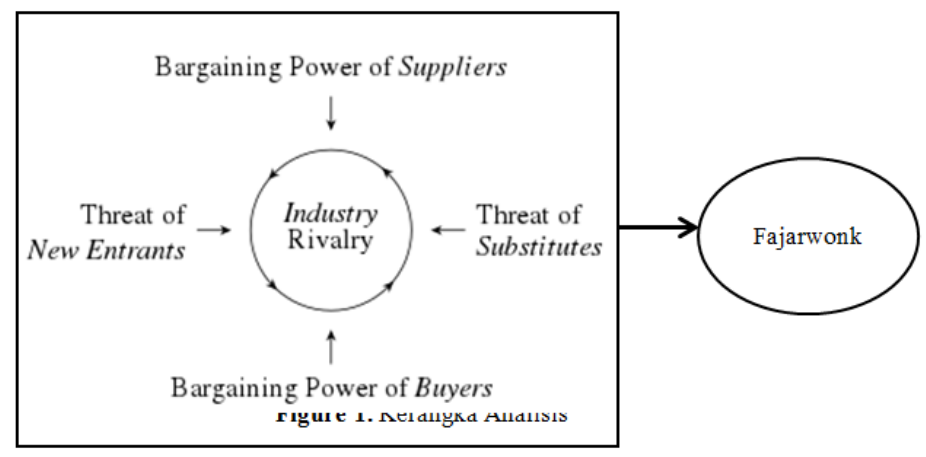

Fig. 1. Kerangka Analisis

\section{Method}


This research is a qualitative research to find out and get information. Qualitative research was conducted using in-depth interviews (interviews with MSMEs). In this study also used a structured questionnaire consisting of 5 categories, where each category represents competitive strength. [5] [6] The subjects in this study were the Fajarwonk Bengkulu.

This research was conducted in September and October 2020 with the aim of analyzing the attractiveness of Fajarwonk UMKM products by using five Force Analysis [7] and evaluating the perceptions of the five Force Analysis as well as creating a framework of opportunities and determining areas of profitable strategic change.

\section{Five Force Analysis}

\subsection{Threat of new entrants}

The threat of newcomers to hanging leather handicrafts in Bengkulu Province is estimated to be quite high, this can be seen from the considerable number of craftsmen and entrepreneurs of hanging leather who provide handicrafts in the form of souvenirs which are marketed at outlets in tourist areas. The products marketed by craftsmen and hanger-skin entrepreneurs range from brooches to bags that have the characteristics of Bengkulu Province, namely Rafflesia Flowers. Despite the increasing number of new entrants, a significant obstacle for new competitors is the marketing of products that are still not particularly attractive to consumers. Most of the hanging leather handicraft products are indistinguishable and do not have a brand that can become a characteristic of product marketing, so that the marketing investment, especially promotion, is still small. Access to raw materials and technology for manufacturing products that are still difficult is also a conclusion based on the results of interviews conducted showing that there are significant obstacles for newcomers, in other words, the threat of newcomers is quite low. The average perceived tariff rate for this competitive power of the model is 1.25 .

\subsection{Bargaining power of buyers}

Fajarwonk handicraft products are distributed directly to consumers and government agencies and often participate in exhibitions held at the tourism office both within the Province and outside Bengkulu Province. The dominance of consumers, namely the middle to upper society which is dominated by exclusive bag products for office women, the number of buyers is not always constant, depending on the number of requests. In marketing Fajarwonk products have employees who can provide information about products being marketed and have product information with official permission, even fajarwonk is often asked to provide training on the management of hanging skin into products that are competitive in the market. The market share of Fajarwonk MSME products is not constant depending on the level of people's purchasing power. This shows that the bargaining power of buyers is high. Based on the conclusion from the results of the interviews conducted, it is the power of buyers of Fajarwonk MSME products is high with an average of 3.27 .

\subsection{Bargaining power of suppliers}

The basic raw material for Fajarwonk UMKM products is hanging skin, hanging skin farmers are the most important supplier in this business. The owner of Fajarwonk stated that the 
price offered by hanging skin farmers is very high, even though the hanging skin is the basic raw material which greatly influences the production process. The difference in price and quality of hanging leather has an effect on the final quality of the product produced. The difficulty of raw materials and the management of raw materials into finished materials that require special skills requires that workers have good skills and competencies, especially in current technological developments. The data obtained through interviews conducted led to the conclusion that the bargaining power of hanging skin suppliers at fajarwonk MSMEs was high as indicated by the model size of 3.25 .

\subsection{Threat of substitute products}

Products produced by Fajarwonk UMKM are included in the complementary product category. Therefore, according to the owner, the level of need for the product is not too high where the community needs a substitute product of $2 \%-5 \%$ and the community is very easy to find replacement products. Based on the interview, it can be concluded that the threat of substitute products is quite high with a model value of 1.07.

\subsection{Rivalry among existing firms}

The hanging leather handicraft industry in the Bengkulu region is growing, the public's interest in the various hanging leather products encourages business growth which is increasing every year. Public awareness of the quality of products made from hemp leather such as bags has had an impact on the growth and development of this hanging-based business. The increasing number of hemp skin craftsmen who require the same basic materials have resulted in high demand for raw materials and prices at the farm level. The high level of competition in the handicraft industry owned by Fajarwonk is seen in the measured average of 4.02.

\subsection{Identifikasi faktor kunci kesuksesan}

After a thorough analysis of all the forces affecting Fajarwonk MSMEs, it can be concluded that the level of competition in the handicraft business of hanging leather is high, but the threat from newcomers is quite low. The bargaining power of customers is high because of different levels of purchasing power and the target market share is the middle to upper class market share. The bargaining power of suppliers even though they are rated as high enough can affect the quality of the final product. The results of the analysis can be seen in Figure 2.

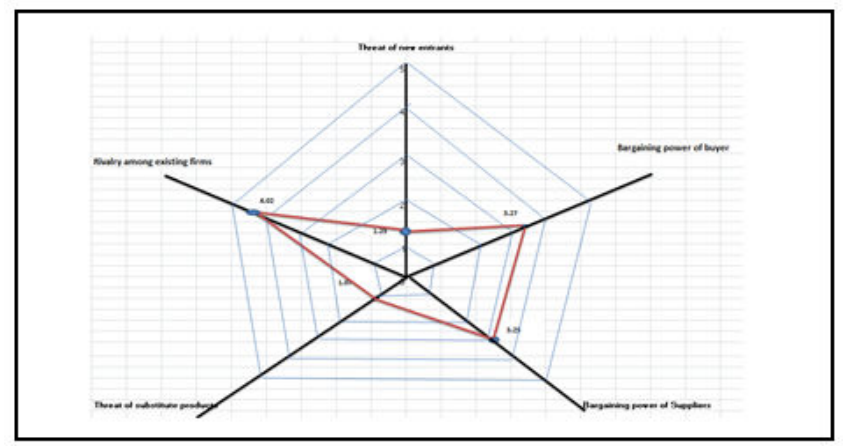

Fig. 2. Hasil penelitian 
The threat of substitute products in this study is quite high because the product produced is not a basic necessity but rather a complement which can be replaced with other products if consumers do not find a product that meets expectations. The threat of substitute products for complementary products is not the same as products which are daily necessities. The threat posed by substitute products depends on the price and performance of the product for which the customer is intended to meet basic needs. Lower prices or better quality and competitiveness have a higher probability of substituting another product.[8]

Buyers can become a threat if they haggle over prices or raise costs by demanding better quality. The size and concentration of customers are the power for buyers, buyers are in power if there are few products but buyers need a lot of products. markets that can be developed for the long term. However, the obstacle faced in creating innovative products is the lack of quality suppliers of raw material for hanging skin, so that further management is still needed before carrying out the product production process. Some of the strategies that Fajarwonk can develop include:

a. Adding more innovative product differentiation at a fairly affordable price while maintaining quality.

b. Opening special outlets that are easily accessible to consumers, so that consumers can easily choose the desired product.

c. Maintaining product quality supported by technological developments so as to produce more according to market demand.

d. Doing product marketing through affiliate marketing, so that the product is better known and easily accessed by consumers.

\section{Conclusion}

Based on the results of the research conducted it can be concluded that the level of competition in the handicraft business of hanging leather is quite high, however, the threat from newcomers is quite low, while the bargaining power of customers is high due to different levels of purchasing power and the target market share, namely the middle to middle class people on. The bargaining power of suppliers is considered quite high and affects the quality of the final product. The strategies that Fajarwonk can develop are based on the identification of the five force model, namely: Adding more innovative product differentiation while maintaining quality, opening special outlets that are easily accessible to consumers, maintaining product quality supported by technological developments, marketing products through affiliate marketing.

\section{References}

[1] I. Y. Niode, "Sektor umkm di Indonesia: profil, masalah dan strategi pemberdayaan," $J$. Kaji. Ekon. dan Bisnis OIKOS-NOMOS, vol. 2, no. 1, pp. 1-10, 2009, [Online]. Available:

https://repository.ung.ac.id/kategori/show/uncategorized/9446/jurnal-sektor-umkm-di-i ndonesia-profil-masalah-dan-strategi-pemberdayaan.html.

[2] Lili Marlinah, "Peluang dan Tantangan UMKM Dalam Upaya Memperkuat Perekonomian Nasional Tahun 2020 Ditengah Pandemi Covid 19," J. Ekon., vol. 22, no. 2, pp. 118-124, 2020. 
[3] A. F. Thaha, "Dampak Covid-19 Terhadap UMKM di Indonesia," J. Brand, vol. 2, no. 1, pp. 147-153, 2020.

[4] P. Jimmy and R. H. Mustamu, "Analisis Strategi Pada Perusahaan Plastik Dengan Porter Five Forces," Agora, vol. 3, no. 1, pp. 736-741, 2015.

[5] Ž. Dulčić, V. Gnjidić, and N. Alfirević, "From Five Competitive Forces to Five Collaborative Forces: Revised View on Industry Structure-firm Interrelationship," Procedia - Soc. Behav. Sci., vol. 58, pp. 1077-1084, 2012, doi: 10.1016/j.sbspro.2012.09.1088.

[6] M. By and M. E. Porter, "Designing Marketing Strategy Using the Five Competitive Forces of Small Bakery in Croatia," In ternation a lJournalofManage me n t C a s e s, pp. 376-386.

[7] M. E. Porter, "Towards a dynamic theory of strategy," Strateg. Manag. J., vol. 12, no. 2 S, pp. 95-117, 1991, doi: 10.1002/smj.4250121008.

[8] W. Yunna and Y. Yisheng, "The competition situation analysis of shale gas industry in China: Applying Porter's five forces and scenario model," Renew. Sustain. Energy Rev., vol. 40, pp. 798-805, 2014, doi: 10.1016/j.rser.2014.08.015.

[9] G. D. Karagiannopoulos, N. Georgopoulos, and K. Nikolopoulos, "Fathoming Porter's five forces model in the internet era," Info, vol. 7, no. 6, pp. 66-76, 2005, doi: $10.1108 / 14636690510628328$. 